Document de Recherche du Laboratoire d'Économie d'Orléans DR LEO 2016-17

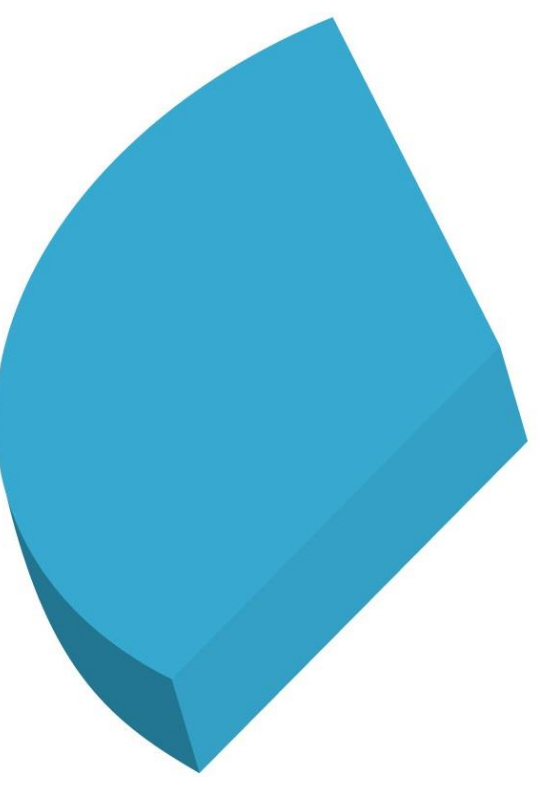

Don't Touch My Road. Evidence from India on Affirmative Action and Everyday Discrimination

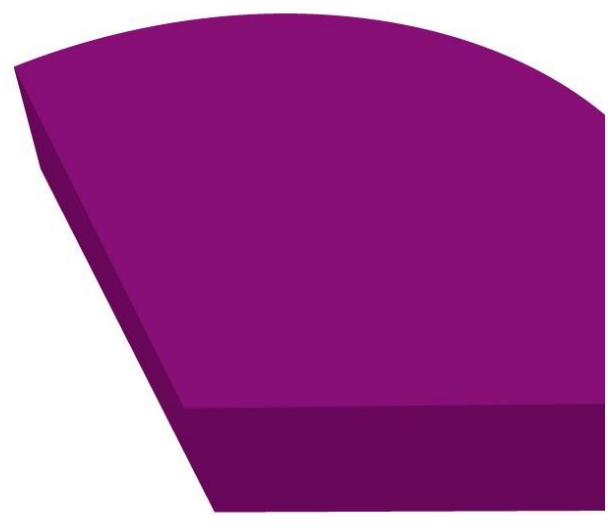

Victoire GIRARD

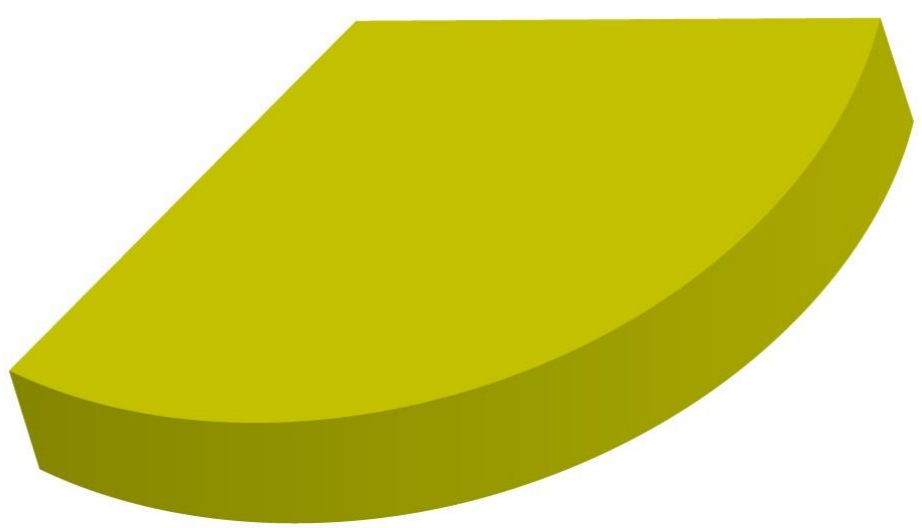

Mise en ligne : 10/11/2017

Cette nouvelle version remplace celle du 14/10/2016

à paraître dans World Development 


\title{
Don't Touch My Road. Evidence from India on Affirmative Action and Everyday Discrimination
}

\author{
VICTOIRE GIRARD*
}

July 2017

\begin{abstract}
This article investigates whether affirmative action, in the form of electoral quotas, affects groupbased discrimination. The redistributive effect of quotas is subject to debate, and their ultimate target is discrimination. To identify the effect of electoral quotas, I take advantage of their rotation across space and over time in India. To proxy discrimination, I use a measure of caste-based exclusion from a public infrastructure (namely, streets). I document that ongoing quotas decrease the likelihood of caste-based exclusion by about one fifth for members of the marginalized castes labeled Scheduled Castes. However, the effect does not last. From a policy-maker's perspective, these results are mixed. These results are consistent with a temporary change in the behavior of members of the dominant castes after a one-shot electoral quota. These results are inconsistent with either a change in the stereotypes of members of the dominant castes, or a change in the aspirations of members of the lower castes.
\end{abstract}

Keywords: Discrimination, Affirmative action, Quota, Inequality, Caste, India

JEL D63, D74, J15, O12, O53

*LEO, Univ. Orléans, CNRS, UMR 7322, F-45067, Orléans, France, Paris, France. Contact: victoire.girard@univorleans.fr. I thank the editor, anonymous referees, Jean-Claude Berthélemy, CatherineBros, Abhishek Chakravarty, Cléo Chassonnery-Zaïgouche, Lisa Chauvet, Marcel Fafchamps, Irma Clots-Figueras, Diana Cheung, Nelly El-Mallakh, Véronique Gille, Zaneta Kubik, Chloé Leclère, Charlotte Levionnois, Daniel Mirza, Thaïs Nuñez-Rocha, Sophie Piton, Silvia Salazar, Eve Sihra, Gerhard Toews, and participants at the LEO seminar and the ARDIS, JMA, DIAL, AFSE, EEA, SMYE LAGV and ISI conferences for their feedback. I thank Andrew Foster for providing the data and the Region CentreVal de Loire for funding through the APR-IA MUTMOND project. 


\section{Introduction}

Discrimination prevents equality of opportunity, and evidence abounds on the persistence of discrimination (Bertrand \& Duflo, 2016). In this context, affirmative action is frequently used to fight discrimination, and ultimately target equal opportunities. Affirmative action is particularly appealing to governments because it allows them to immediately and visibly change outcomes of interest, for example, the racial composition of university students. However, affirmative action is also controversial: people outside its target can feel discriminated against. ${ }^{1}$ On this ground, the US Supreme Court has banned explicit racial quotas in 1978 (subtler forms of affirmative action are still legal, and challenged, for example in the case of Fisher v. University of Texas at Austin, 2016). Quotas, in particular electoral quotas, nonetheless remain widespread. More than 100 countries have electoral quotas for women, and 38 countries have electoral quotas for other minority groups (respectively, Krook, 2009; Reynolds, 2005). Proponents of quotas advocate them as transitory tools. The objective is to repeal quotas, once they have allowed the society to reach a non-discriminatory equilibrium. This article stems from the idea that electoral quotas are more likely to have long lasting effects if they change the way that people interact with each other. Otherwise, the risk is to go back to a pre-quota (discriminatory) equilibrium once quotas are repealed. This question is all the more important now that the redistributive effect of electoral quotas is subject to debate. $^{2}$

I investigate whether affirmative action, in the form of electoral quotas, affects caste-based discrimination in India. Members of the marginalized Scheduled castes (henceforth, SCs), and other marginalized groups, benefit from quotas in the form of seat reservations in local political assemblies (the Gram Panchayats). The SCs, who used to be called untouchables and often refer to themselves as dalits (meaning the oppressed), still face widespread discrimination. To measure discrimination, I exploit a survey question asking households whether they were excluded from some streets because of their caste (i) at the moment of the survey and (ii) 10 years before. In the Hindi Belt, the heartland of India, $44.5 \%$ households members of the SCs declared in 2006 that some streets were off-limits due to their caste. Yet the practices of untouchability and caste-based discrimination have been anti-constitutional since 1949. The startling figure of street exclusion confirms the persistence of caste-based discrimination and calls for more research on how to achieve equality of opportunities.

While discrimination is notoriously difficult to measure, declarations of exclusion from public goods such as streets provide a good starting point for several reasons. First, from a methodological perspective, a declaration of street exclusion is an original proxy of discrimination. Even if the variable of exclusion is unlikely to disclose the absolute level of caste-based discrimination, changes in the variable over time 
allow me to study changes in caste-based discrimination. This strategy is in line with Bertrand and Duflo's idea that imperfect measures of absolute discrimination can be used to evaluate anti-discriminatory interventions (Bertrand \& Duflo, 2016). Second, from the perspective of positive economics, street exclusion proxies taste-based discrimination, the form of discrimination which is costly to society (Becker, 1957). Streets are a public good, and street exclusion means that discriminatory agents are willing to pay - be it money or the opportunity cost of the time spent to enforce the exclusion - to ensure that other agents are excluded. Last but not least, from an ethical, perspective, street exclusion is a blatant negation of equality of opportunity. ${ }^{3}$ Street exclusion makes it difficult or impossible, for members of some castes, to access some areas of their village. Mechanically, such exclusions limit access to the public goods or jobs that are in these areas.

My identification strategy relies on the way that quotas are allocated at each election, and on the assumption that caste quotas have heterogeneous effects on households from different castes. The states' local administrations allocate quotas within each state and the allocation rule is state-specific. It can be random or depend upon village-level characteristics. I identify the effect of electoral quotas on street exclusions through within-village and within-caste variations over time. Village year fixed-effects allow me to control for time-varying village-level characteristics (including any characteristic that administrations may use to allocate quotas). The panel dimension of the data also allows me to account for caste-specific trends and time-invariant unobservables at the household level.

I document a large and significant effect of electoral quotas on low-caste members' access to streets. SC quotas decrease street exclusions by about 10 percentage points for the households of the SCs. Unfortunately, the effect is not permanent: it vanishes once the quote comes to an end. To put things in perspective, since roughly every second household reports exclusion in the SC, sample ongoing quotas decrease the likelihood of street exclusion by about one fifth. These results are robust. In particular, they are independent of the share of SCs in the village (some administrations use caste shares to allocate quotas), and are robust to the omission of the 1996 variable of exclusion (which comes from a recall question).

My research question is most closely related to the investigation by Chauchard (2014) of the impact of electoral quotas on the discriminatory beliefs and intentions of members of dominant groups. I complement Chauchard (2014) in two respects. First, his data design prevents him from assessing the effect of quotas over time. Indeed, he uses cross-sectional data that he collected in Rajasthani villages where either an SC quota was being implemented for the first time, or no SC quota had ever taken place. Second, his analysis relies on what members of dominant castes stated to be their feelings and action plans towards low castes. He convincingly makes sure - both in the design of his questionnaire and 
the interpretation of his results - that statements are not strategically biased. However, as underlined by LaPiere's seminal work, actions may differ from statements (LaPiere, 1934). I complement Chauchard's work with a study of discrimination from the perspective of members of the low castes, and with data covering three electoral terms (and any quota occurring during these terms).

More broadly, my results contribute to the literature on the link between electoral representation and people's actions - meaning the actions of constituents rather than leaders. Almost all the articles in this literature focus on political representation for females, and few of them address directly the question of discrimination. However, this rich literature underlines different channels through which electoral representation may affect discrimination. These potential channels are: the actions of the minority leader (Besley, Pande, Rahman, \& Rao, 2004), a change in either the mindset or actions of the minority members (respectively, Dunning, 2010; Iyer, Mani, Mishra, \& Topalova, 2012), and a change in either the mindset or actions of the majority members (respectively, Bhalotra, Clots-Figueras, \& Iyer, 2013; Chauchard, 2014). For simplicity, the whole article refers to the group who is considered as discriminated against as the minority group, even if this group may be numerically important, as is the case with women.

Building upon the existing literature and auxiliary results, I suggest two channels that are consistent with the main results of the article: either the SC leader plays a pivotal part while in office (enforcing or negotiating a change of behavior of members the dominant castes), or there is a change in the perception of the social norm by members of the dominant castes. In both cases, members of the dominant castes change their behavior for the duration of the electoral term, which is consistent with a reduction of street exclusions during SC quotas. A one-shot quota is already enough to observe this effect. Auxiliary results are inconsistent with alternative channels, such as a change in the stereotypes held by members of the dominant castes, or a change in the aspirations of members of the lower castes.

\section{Institutional context and literature}

This article exploits a system of caste quotas for the head's seat in Indian local political councils. Caste quotas aim at fighting the legacy of caste discrimination in India. This section briefly introduce the context in which this fight is taking place.

\subsection{Castes}

Several caste features induce a strong inertia for caste-based discrimination, and may justify the implementation of affirmative action policies. First, castes are hereditary, exclusive and virtually unchangeable at the the household level. Second, castes are ordered on a social status ladder, which matches a purity 
ladder, where so-called "ritual pollution" may happen between people of different purity statuses if some rules to prevent this pollution are not followed. Third, and closely linked to the second aspect, caste groups are segregated: this has led to forms of spatial segregation, and to historically very strict matrimonial segregation. These theoretical features translate into preferences or rules affecting everyday life interactions. Up until now, castes have structured business networks (Munshi, 2011), the amount of public goods available in an area (Banerjee \& Somanathan, 2007), and severely curbs mate selection (Banerjee, Duflo, Ghatak, \& Lafortune, 2013), while revealing subjects' castes in an experiment significantly affects their performances (Hoff \& Pandey, 2006, 2014).

In this article, I always refer to castes as the broad groups used by the Indian administration rather than the thousands of jatis which represent the form that caste takes in everyday life. Indeed, the Indian administration allocates electoral quotas after recording castes under four broad groups: Scheduled Castes (SC), Scheduled Tribes (ST), Other Backward Castes (OBC), and Other Castes (OC). The SCs and STs form the traditionally most disadvantaged groups. The OCs stand at the top of the ritual social status hierarchy, which matches to a large extent the economic hierarchy still prevalent today (A. Thorat, Vanneman, Desai, \& Dubey, 2017; Zacharias \& Vakulabharanam, 2011). The OBC form a heterogeneous group of castes that sometimes suffer from discrimination and sometimes are locally dominant (Anderson, 2011).

I focus on caste-based discrimination against members of the SCs. The Scheduled Castes are particularly backward castes; their members used to be considered "untouchables". Today, members of the SCs have adopted the term "dalit" (meaning the oppressed). SCs are significantly poorer than the rest of the population (Borooah, Diwakar, Mishra, Naik, \& Sabharwal, 2014; Deshpande, 2000) and still suffer from caste based-discrimination. Despite the constitutional ban, in 2012, 30\% of the rural respondents to the Indian Human Development Survey straightforwardly reported that they practiced untouchability. This practice translates in a variety of ways, including the exclusion of SCs from markets, or systematic deviation from market prices to their disadvantage (Thorat, Mahamanlik and Sadana's survey results in S. Thorat \& Newman, 2010), constraints on access to credit (Kumar, 2013), spatial segregation (Deliège, 2004), widespread exclusion from public goods (Hanna \& Linden, 2012; Shah, Mander, Thorat, Deshpande, \& Baviskar, 2006), and a specific pattern of crimes against them (a pattern consistent with the enforcement of caste-based discrimination, Bros \& Couttenier, 2015; Sharma, 2015).

\subsection{SC exclusion from streets}

I am interested in a particular form of caste-based discrimination: street exclusion. Spatial segregation of members of the SCs is a widespread practice that both activists, scholars, and the legislator take in 
account as a central aspect of caste-based discrimination.

Concretely, one of the beliefs in Hinduism is that members of non SC castes shall limit contact with members of the SCs. As a result, in rural India, SC typically live in a hamlet outside of the main village. As a result, "The Special Rapporteur on racism addressed the issue of segregation in his 1999 Annual Report: In the rural areas especially, the practice of untouchability is said to be very much alive and is reflected in segregated housing, with the [SCs] forced to live at least $1 / 2 \mathrm{~km}$ from the rest of the villagers, and in the prohibition for them to use the wells, the shared water source. Segregation also reportedly exists in the schools, public services and public places" (Human Rights Watch, 2007, p. 45).

Explicit descriptions of the practice of street exclusion are scarce. However, the work of Macwan et al. (2010) on "Understanding untouchability" provides exceptional insights. ${ }^{4}$ The survey was designed by a multidisiplinary team of scholars and activits and conducted between 2005 and 2008 in 1,589 villages of the state of Gujarat. The survey describes 98 untouchability practices, several of them pertaining to spatial segregation. For example, (followed in parenthesis, by the prevalence rate of the practice in the surveyed villages) : "Dalits [SCs] may not rent houses in a non-Dalit locality, but must live within the Dalit community”(98\%); "When Dalit relatives have died, processions cannot enter the city from the main street" (55.7\%); "When untouchability is practiced, a Dalit postman cannot enter the streets of non-Dalits, he is forced to call other non-Dalits to come out to make the delivery" (43.2\%). "Gauchar (public grazing land) may be inaccessible to Dalits when untouchability is practiced" (49.3\%). These few examples outline the diversity and prevalence of spatial segregation toward members of the SCs.

The persistence of such practices is all the more striking that it is costly. Take the example of the villages where a non SC distributes the mail in the non SC streets. The practice of untouchability has a clear time cost for the people delivering the mail instead of the SC postmen. But still, non-SC members prefer to deliver their own mail to themselves in more than $40 \%$ of the villages of the survey rather than letting SC postmen doing their job.

Moreover, the Indian legislator aims to stop caste based discrimination and punish people who discriminate. The Scheduled Castes and Scheduled Tribes (Prevention of Atrocities) Act, 1989 recognizes the symbolic weight of some offenses and grants that their perpetrators receive a harsh punishment. Preventing members of the SCs from moving around is among the offenses listed in the act in its article 14 . The exact description is : "Whoever, not being a member of a Scheduled Caste or a Scheduled Tribe [...] Denies a member of a Scheduled Caste or a Scheduled Tribe any customary rite of passage to a place of public resort or obstructs such members so as to prevent him for using or having access to a place of public resort to which other members of public or any section thereof have a right to use or access to." Such a description is broad enough to encompass the examples taken from Macwan et al. (2010) work. Spatial 
segregation is thus both a widespread aspect of caste-based discrimination, and a punishable offense.

\subsection{Electoral quotas}

Electoral quotas are one of the most prominent policies implemented to fight caste-based discrimination in India. ${ }^{5}$ Local electoral quotas are interesting because, due to the physical proximity of elected leaders, quotas ensure that villagers end up being directly exposed to a low caste leader. ${ }^{6}$ Moreover, many places are affected by these quotas: about 500,000 local political councils have an SC quota for their leader, representing about $18 \%$ of the councils of the country (Ministry of Panchayati Raj, n.d.).

In 1993, the 73rd amendment to the Constitution of India instituted local political councils called Gram Panchayats (GPs hereafter). The GP is the smallest political entity in India; each GP typically encompasses several villages, for example, the GPs in my sample encompass on average 13 villages. The 73rd amendment requires that states delegate a part of their policy making power to GPs. States typically delegated to GPs the maintenance and building of local public goods (such as roads or water devices), and the selection of the households entitled to social programs. Each GP is composed of a council elected for the electoral term of 5 years and a permanent public servant.

I focus the analysis on the Pradhans. Pradhans head the GP councils. Pradhans are important because they have agenda-setting power in panchayat meetings, but no power of veto. They are the only elected council members working full time. Pradhans are elected either directly by GP constituents, or indirectly by members of the GP council.

Crucially, the 73rd amendment requires that every GP ends up having electoral quotas for different minorities (namely, the Scheduled Castes and Tribes, and females). ${ }^{7}$ As a consequence of this requirement, during a quota, a village ends up with a Pradhan from a given minority independently of the villagers' actions, the political landscape, or the relation between castes in the village. Quotas are allocated by each state administration. Quotas for the Pradhan's seat mean that this seat is reserved for one term at a time to either a member of a low caste, or a female, or someone who is both. Quotas rotate between villages. The allocation rule differs from one state administration to another (the precise rule is not publicly known for all states). Some administrations allocate quotas at random (for example in West Bengal, Bardhan, Mookherjee, \& Parra-Torrado, 2010), while others list villages according to the proportion of their population belonging to the low castes, and use these lists to allocate quotas (for example in Rajasthan, Chauchard, 2014). The proportion of caste quotas varies between states: the proportion is determined by the share of low castes in the population of the state. Regarding gender quotas, they are imposed in a third of all constituencies, and rotate at random. I focus on the SC quotas for Pradhan seats in Gram Panchayats. 


\subsection{Literature on the impact of electoral representation on people's actions}

The electoral representation imposed through SC quotas may impact people's actions and inter-group relations through different channels. Let me present the channels according to whom they identify as the key actors: the political leader (who comes from the minority group), the members of the minority group, or the majority.

A minority leader can improve access to public goods for her peers. Improved access my circulate through the funding of new public goods (Besley et al., 2004), or through improved access to existing public goods. For example, the tremendous increase in crimes registered against females in the 1990s in India is, at least partly, due to the fact that police officers have been more responsive to female complaints since the implementation of electoral quotas (Iyer et al., 2012). A minority leader can also directly increase the opportunities for her peers by exploiting her network to help them (Gille, 2014).

As for the minority members, quotas can affect either the probability that they will voice their concerns, or their within-group solidarity, aspirations, or feelings of legitimacy. First, quotas provide a leader for the members of the minority, a leader who can help them to coordinate (Hirschman, 1970). Second, quotas underline the distinction between the minority and the majority groups, which can increase the solidarity within the minority group (Dunning, 2010). Third, quotas provide members of the minority with a role model. Such a model can shape aspirations, for example those to do with educational achievements or entrepreneurship (respectively Beaman, Duflo, Pande, \& Topalova, 2012; Ghani, Kerr, \& O'Connell, 2014, although in the later, changes in aspirations cannot be disentangled from changes in entrepreneurship costs). A role model can also shape the feelings of legitimacy of members of the minority (Iyer et al., 2012).

Turning to members of the majority, exposition to a political leader from the minority can affect either their personal stereotypes (a private cognitive bias toward members of the minority), or their perception of norms of public interactions (whether it is appropriate to publicly discriminate against minority members, at a given level of cognitive bias). Indeed, in line with Allport's contact theory, the election of a female leader reduces both voters' stereotypes on gender roles, and parties' biases against women candidates (respectively Beaman, Chattopadhyay, Duflo, Pande, \& Topalova, 2009; Bhalotra et al., 2013). Alternatively, Chauchard (2014) documents that, even if personal stereotypes remain unchanged, quotas can change the stated - social and legal - norms of members of the majority.

The incidence of an SC quota in a GP may affect caste-based discrimination through one or several of the above channels. 


\section{Data}

\subsection{Dataset}

I investigate empirically whether SC quotas affect caste-based discrimination. The empirical analysis relies on the last round of the Rural Economic and Development Survey (REDS), undertaken in 2006 by the National Council for Applied Economic Research. ${ }^{8}$ The REDS 2006 contains both a survey at the village level and a complete census of the villagers. For the village survey, enumerators relied on a minimum of three independent sources to fill in each item of the village survey. For the household census, enumerators surveyed household heads (respondents are on average 47 years old and $90 \%$ of them are males. The REDS encompasses information on caste-based discrimination at the household level, on village level electoral quotas, and on all the control variables I use but one. The only information missing in the REDS is the share of SC households in 1996. To obtain the share of SC households in 1996, I merge village-level data from the 2001 Census to the REDS 2006 data, so that I have information on the share of SC households in each village both in 2001 and 2006. A linear extrapolation based on known SC shares and time gives me an estimate of the SC share in each village for the year 1996.

The final sample of the article encompasses 40,047 households spread over 95 villages of 5 Hindi Belt states (namely the states of Bihar, Haryana, Madhya Pradesh, Rajasthan and Uttar Pradesh). It is a subset of the national sample which encompasses 115,000 households from 242 villages spread over the 17 major Indian states. The Hindi Belt is particularly suitable for studying the link between electoral quotas and group-based discrimination because it displays more tensed inter-caste relationships than does southern India (Borooah, in press; Jaffrelot, 2003, , however, the main results are robust to the sample definition). Politics is also more caste-oriented in Hindi Belt states, where the Scheduled Castes have risen as a political group (Jaffrelot, 2003).

\subsection{Caste-based Street Exclusions}

The explained variable tells whether respondents report certain streets of their village to be off-limits for them, due to their caste identity. The variable is collected in the household census of the REDS 2006 for (i) the moment of the survey and (ii) 10 years before, through a recall question (section 4.3 shows that answer to the recall question are consistent). The question for caste-based exclusion at the moment of the survey is "Have you or any member of your family been prevented from entering any street within the village because of your caste now?" Concretely, street exclusions mean that it is difficult or impossible for members of the low castes to access some areas of their village. This exclusion is possible because of the spatial segregation of castes in traditional villages (Deliège, 2004; Human Rights Watch, 2007; 
Figure 1: Street exclusion declarations by members of the SCs in 1996 and 2006.
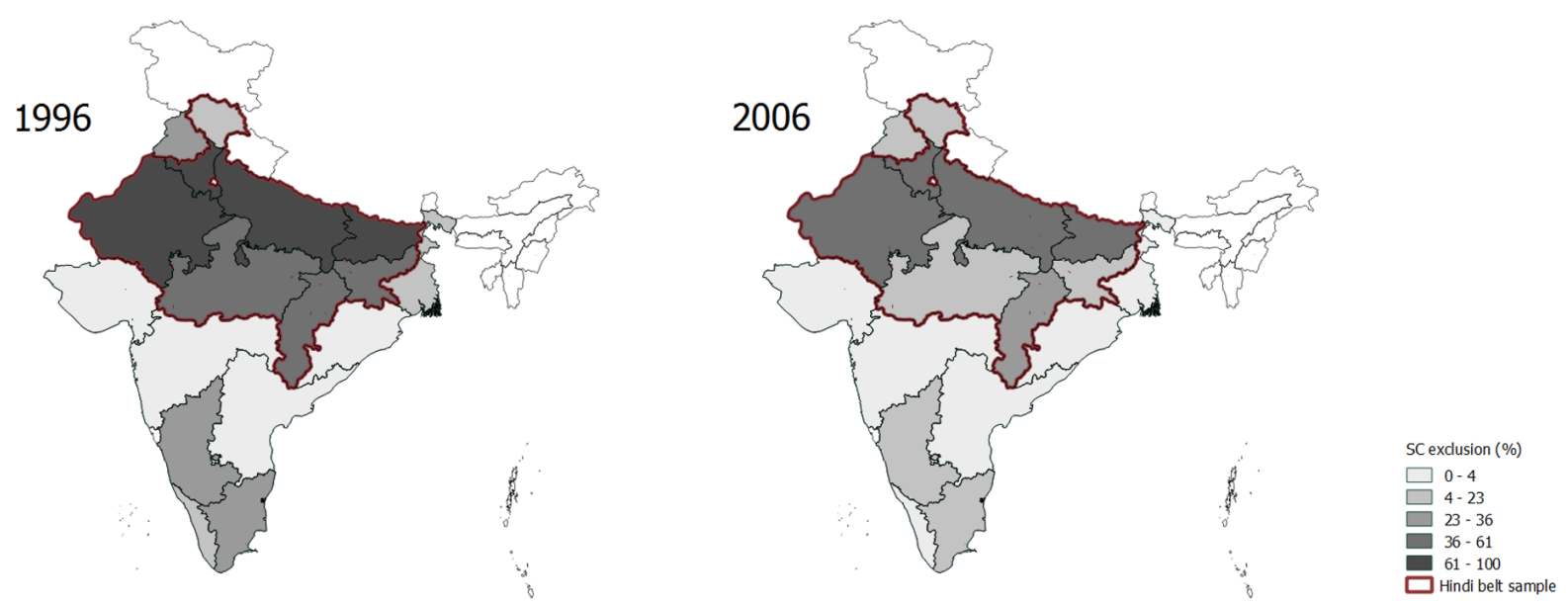

Macwan et al., 2010).

To be consistent with the formulation of the question in the survey, I tend to refer to the variable as a measure of the evolution of street exclusions. However I acknowledge that answers to the survey question may depend on several elements such as both the de facto rule enforced in the village, and what members of the SCs perceive as a legitimate behavior for themselves. I discuss the channels of the results in section 5.1 and show that the change in answers that is induced by SC quotas is only consistent with a change in the the de facto rule (rather than a change in perceptions).

Figure 1 shows the evolution of declarations of street exclusions, between 1996 and 2006, across states, for members of the SCs (it averages household answers at the state level). The difference between states of the Hindi belt and the rest of India is clear: the average exclusion figure in Hindi Belt states is $65 \%$ in 1996 , against $12 \%$ in other states.

Comparing street exclusions across castes, as expected, the exclusion rates presented in Table 1 are the highest for members of the SCs. In 2006, $44.5 \%$ households of the SCs suffered from street exclusions. Although both SCs and STs are associated with a low social status, the corresponding figure for members of the STs is 7\%. This great divergence from members of the SCs can be traced back to the specific settlement patterns of each group. SCs are part of traditional multi-caste villages. Historically, SCs handled low-status jobs at the service of higher castes. The STs descended from tribes and traditionally live in isolated autonomous villages. ${ }^{9}$ The non-null exclusion rates of OBC and OC may be traced back to specific local wealth patterns, difficulties in setting the right frontier for which sub-caste is a low caste, or measurement errors. ${ }^{10}$ 
Table 1: Street exclusions and group shares in states of the Hindi Belt

\begin{tabular}{lcccc}
\hline $\begin{array}{l}\text { Caste } \\
\text { category }\end{array}$ & $\begin{array}{c}\text { Population } \\
\text { share }\end{array}$ & $\begin{array}{c}\text { Share excluded } \\
1996\end{array}$ & $\begin{array}{c}\text { Share excluded } \\
2006\end{array}$ & $\begin{array}{c}\text { Households which gained } \\
\text { access from 1996 to 2006 }\end{array}$ \\
\hline SC & $20.0 \%$ & $65.0 \%$ & $44.5 \%$ & 2,076 \\
ST & $6.5 \%$ & $31.4 \%$ & $7.2 \%$ & 779 \\
OBC & $50.8 \%$ & $5.5 \%$ & $4.0 \%$ & 520 \\
OC & $22.4 \%$ & $1.6 \%$ & $1.3 \%$ & 62 \\
\hline
\end{tabular}

In the empirical analysis, I circumvent many sources of measurement error by comparing differences in street exclusion declarations across places and over time. The street exclusion declaration of one household head is an imperfect measure of the absolute level of discrimination faced by all members of the household. The main concern is that each household head declaration may be biased according to the head's and surveyor's age, sex, wealth, mood of the day, etc. However, looking at the change between the 1996 and the 2006 answers of a given household head, and comparing this change across castes and villages, allows me to get rid of any head, surveyor, caste or village specific measurement error. What I focus on is how answers change during SC quotas rather than their absolute level.

Changes in street access are thus likely to disclose relevant information on the evolution of castebased discrimination across places, across castes, and over time. I exploit these changes to measure how caste-based discrimination evolves during caste quotas. Using change in street access to evaluate the impact of caste quotas for Pradhans is similar in spirit to the use of Implicit Association Tests to evaluate the impact of gender quotas for Pradhans on gender bias in Beaman et al. (2009). As outlined by Bertrand and Duflo (2016), even when the absolute level of some measures of discrimination is hard to interpret as is the caste with both Implicit Association Tests results and the exclusion variable I am using - their changes in response to a treatment still provide valid information on the impact of a treatment.

\subsection{Caste-based electoral Quotas}

The study focuses on SC electoral quotas in Gram Panchayats. Each village of the survey belongs to a different GP, hence the survey covers 95 GPs. I observe SC quotas in 30 of the 95 villages surveyed. The survey collects electoral information over three periods: the ongoing electoral term, and the two previous terms. As a result, I know which villages have an SC quota in 2006 (the moment of the survey), in 1996 (the moment of the recall question for street exclusions), and in the intermediary electoral term (which took place between 1996 and 2006 since, even if the year of election differs across states, electoral terms last 5 years everywhere).

An SC quota means that the Pradhan's seat is reserved to a member of the Scheduled Castes. An 
Table 2: Baseline village characteristics, by treatment group (SC quota in each electoral term).

\begin{tabular}{|c|c|c|c|c|c|c|}
\hline & \multicolumn{3}{|c|}{ SC quotas in 1996} & \multicolumn{3}{|c|}{ SC quotas in 2006} \\
\hline & no quota & quota & $\mathrm{P}>|\mathrm{z}|$ & no quota & quota & $\mathrm{P}>|\mathrm{z}|$ \\
\hline \multirow[t]{2}{*}{ population } & 440 & 242 & & 411 & 474 & \\
\hline & (347) & $(147)$ & & (328) & (397) & \\
\hline \multirow[t]{2}{*}{ share SC } & 0.19 & 0.43 & $* * *$ & 0.20 & 0.25 & \\
\hline & $(0.13)$ & $(0.21)$ & & $(0.16)$ & $(0.12)$ & \\
\hline distance district & 42.8 & 27.1 & & 41.3 & 41.4 & \\
\hline headquarter & $(27.6)$ & $(25.2)$ & & (28) & $(26.6)$ & \\
\hline \multirow[t]{2}{*}{ public tap } & 0.36 & 0 & $*$ & 0.32 & 0.38 & \\
\hline & $(0.48)$ & $(0)$ & & $(0.47)$ & $(0.5)$ & \\
\hline \multirow[t]{2}{*}{ street lights } & 0.13 & 0 & & 0.13 & 0.06 & \\
\hline & $(0.33)$ & $(0)$ & & $(0.34)$ & $(0.25)$ & \\
\hline \multirow[t]{2}{*}{ school } & 0.31 & 0.14 & & 0.29 & 0.31 & \\
\hline & $(0.47)$ & $(0.38)$ & & $(0.46)$ & $(0.48)$ & \\
\hline \multirow[t]{2}{*}{ bus station } & 0.39 & 0.14 & & 0.37 & 0.38 & \\
\hline & $(0.49)$ & $(0.38)$ & & $(0.49)$ & $(0.5)$ & \\
\hline \multirow[t]{2}{*}{ post office } & 0.46 & 0.57 & & 0.46 & 0.5 & \\
\hline & $(0.50)$ & $(0.54)$ & & $(0.50)$ & $(0.52)$ & \\
\hline \multirow[t]{2}{*}{ police station } & 0.03 & 0 & & 0.04 & 0 & \\
\hline & $(0.18)$ & $(0)$ & & $(0.19)$ & $(0)$ & \\
\hline Number of villages & 87 & 7 & & 79 & 16 & \\
\hline
\end{tabular}

The table displays the result of two-sample mean comparison tests with the means and standard deviations (in parentheses) of village characteristics according to their treatment status. population is the number of individuals in each village; share $S C$ is the share of each village population belonging to the SCs ${ }^{11}$ distance to the district headquarter is expressed in kilometers. All other variables are dummies taking value one when a village possesses the mentionned equipment. P>|z| tells, for each variable and each treatment (moment of the SC quota), the p-values of the test that the difference between villages with and without an SC quota is zero. *** $\mathrm{p}<0.01, * * \mathrm{p}<0.05,{ }^{*} \mathrm{p}<0.1$.

SC quota is observed only once in each village of the survey. As regards ST quotas, the sample is too small to allow a proper study: only 3 villages display variations in both ST exclusion declarations and ST quotas. ${ }^{12}$ Thus, although ST quotas may have played a part in the improvements of access to streets for members of the STs between 1996 and 2006, I focus my study on SC quotas.

Table 2 investigates whether the allocation of SC quotas has a relationship with village characteristics. Indeed, before each election term, the state administration allocates quotas to a new set of GPs. 
Table 2 presents the results of a two-sample mean comparison test on village level characteristics, by moment of treatment, namely an SC quota observed in 1996 or in 2006. Treated villages differ from untreated villages for the 1996 quotas while the attribution of quotas in 2006 is independent of village characteristics. Indeed, the 1996 SC quotas were allocated to villages with particularly high shares of SC households. This imbalance makes sense since some states rely on the share of SC households to allocate SC quotas. Within each of these states, the GPs with the highest share of SCs in their area of reference, for example the district, received an SC quota during the first election (Table 1 in Chauchard, 2014, replicated in Appendix Table A1, provides an example of such a repartition). As for quotas allocation in 2006, it was independent of village characteristics, making the 2006 election round a particularly interesting natural experiment. The empirical strategy for the main results allows me to account for the correlation between some village characteristics and quota allocation.

\subsection{Street exclusions during SC quotas}

Figure 2 provides a first raw overview of the relationship between SC street exclusions and SC electoral quotas. The figure displays the rate of street exclusions for members of the SCs, in 1996 and in 2006, after splitting the household sample according to when their village have had an SC quota. Villages without any record of SC quotas form the baseline.

Figure 2 is consistent with a decrease in caste-based discrimination due to ongoing electoral quotas. The figure shows that SC households report less exclusions at the moment when there is an SC quota in their village than SC households living in other villages. Indeed, looking at the left panel of 1996 exclusions, the middle bar of the graph is significantly inferior to the baseline bar (since the $95 \%$ confidence intervals represented on the graph do not overlap). It shows us that in 1996, the average exclusion rate of SC households living in a village which had an SC quota in 1996 is significantly below the baseline exclusion rate. We can see a similar story for 2006 exclusions in the right panel of Figure 2. The average 2006 exclusion rate of SC households living in a village which had an SC quota in 2006 (the last bar at the right), is significantly inferior to the baseline exclusion rate in 2006 (the first bar at the left of the 2006 panel).

The rest of the article investigates whether this raw decrease of caste based discrimination during SC quotas holds after accounting for the correlation between some village characteristics and quota attributions, potential measurement errors at the household level, or the general decrease in caste-based discrimination over the period. 
Figure 2: SC street exclusion declarations according to SC quota attributions
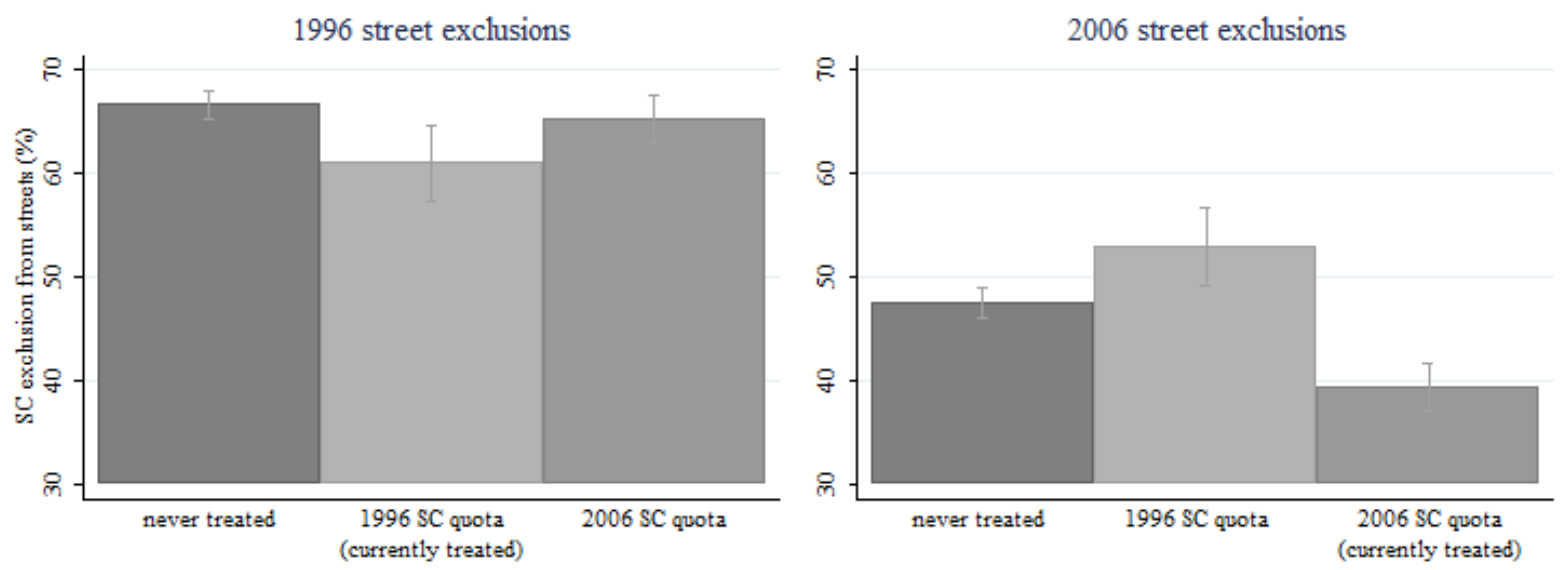

The figure displays the average rate of street exclusion for SC households and its confidence interval (at 95\%). It divides answers into a left panel for 1996 street exclusions and a right panel for 2006 exclusions. Within each panel, I define three samples according to when - if ever - the households' villages experienced a quota and I represent each sample with a different bar. The first bar represents the answers of the 4,946 households spread over the 65 villages who never had a SC quota, the middle bar represents 695 households from 7 villages which had a SC quota in 1996, and the third bar bar comprises 1,768 households from the 16 villages which had a SC quota in 2006. I exclude from the sample of this figure the households living in villages which had an SC quota during the intermediary term. The dash line underlines, for each date, the average exclusion rate in baseline villages.

\section{Results}

\subsection{Empirical strategy}

I investigate the extent to which SC electoral quotas in GPs affect the SC households' declarations of street exclusion. To do that, I exploit three sources of variation. First, I use the rotation of electoral quotas across GPs elections, a rotation determined by the state administration at each electoral term. Second, I treat the household caste as a source of heterogeneous exposure to electoral quotas within each electoral term. Third, I focus the estimation on households whose exclusion declarations changed between 1996 and 2006.

My identification strategy is basically a triple difference procedure that uses electoral quotas as a time-varying, place-varying, and caste-varying treatment. It then compares the change in answers of SC households located in GPs with an SC quota to the change in answers of other households. The other households that I use as a reference are both SC households located in GPs without SC quotas, and non-SC households located in GPs with or without an SC quota. The validity of this empirical strategy 
relies on the assumptions that an SC quota (i) affects only households located in GPs that have been allocated the quota, and (ii) affects differentially SC households and households from other castes. I assume that, in the absence of electoral quotas, the evolution of street exclusions for each caste group would have followed similar trends in all GPs. Available data does not allow me to provide a pre-trend analysis to back up this assumption. However, from the available evidence presented in Table 2 above, villages with and without quotas in 2006 have similar observable characteristics, and the allocation of quotas in previous terms appears to rest on the share of SC households. Thus, villages in 2006 are readily comparable. And for 1996, village $\times$ year fixed effects allow me to partial out any village characteristics that may account for the allocation rule used by the states' administrations (as in Besley et al., 2004). Since the share of SC households is the main determinant of quotas allocation, I also acknowledge that this share have an heterogenous effect on SC households compared to households from other castes. To account for this potential heterogeneity, my favorite specification comprises a variable resulting from the interaction of the share of SC households in the village and a binary variable equal to one for SC households.

To formally evaluate the effect of electoral quotas, I first estimate the following regression:

$$
\text { Street_exclu } u_{i v t}=\alpha S C_{i} \times Q u o t a \_S C_{v t}+F E_{i}+F E_{t}+F E_{v t}+F E_{g t}+\varepsilon_{i v t}
$$

The coefficient of interest is $\alpha$. It tells whether the exclusion declarations of SC households are affected by the fact that their Pradhan is elected on an SC quota.

The explained variable Street_exclu $u_{i v t}$ is a dummy equal to one if household $i$ (from caste $g$ ) in village $v$ declares to have been excluded from streets during year $t$ (where $t=1996,2006$ ). The explanatory variable of interest is the result of an interaction term between $S C_{i}$ and $Q u o t a \_S C_{v t}$. $S C_{i}$ is a dummy equal to one for members of the SCs, Quota_SC $C_{v t}$ is a dummy equal to one if the village $v$ has an SC quota and time $t$. Each of these two variable's main effect is absorbed in the set of fixed effects that I include.

$F E_{i}$ are households' fixed effects, to account for time invariant unobservables at the household level. The household caste is absorbed by these fixed effects as well as the gender, education or even mood of the respondent at the moment of the survey. Households fixed effects also account for village fixed effects. Any time unvarying village characteristic, such as for example a history of excellent - or terrible - inter-caste relationships in a village, or the distance to the district headquarter, is partialed out by the households fixed effects. $F E_{t}$ are time fixed effects to account for the general amelioration in access to streets over the period. $F E_{v t}$ are village fixed effects for each year, to account for possible changes over time at the village level which may be correlated with quota attributions. These village $\times$ year fixed 
effects account for the SC quota incidence at the village level as well as the general atmosphere between castes of the village each year, the Pradhans' abilities, and any other characteristic of the village a given year. $F E_{g t}$ are caste fixed effects for each year, to account for any trend of change at the SC group level which would be independent from SC quotas, for example a change in the skills or economic status that would happen nationwide. Thus, the coefficient of interest $\alpha$ is identified from the variation in answers that happens during SC quotas and that is independent from all the fixed effects.

I estimate equation 1 using a linear probability model, given the important number of fixed effects. ${ }^{13}$ The error term $\varepsilon_{i v t}$ is clustered two ways, to account for shocks both at the level of the caste group within each village and year (the scale of the independent variable of interest), and at the level of the household. $^{14}$

\subsection{Main Results}

Table 3 documents that an SC quota decreases by about 10\% the likelihood that an SC household will declare a caste-based street exclusion. The effect is large, stable, and statistically significant in all specifications (from the most parsimonious specification in column 1 to the specification with the maximum set of controls in column 5). The magnitude of the effect of the SC quotas is important given that the share of SC households reporting an exclusion decreased by 20 percentage points between 1996 and 2006, reaching a share of exclusions of $44.5 \%$ in 2006.

The relationship between SC quotas and exclusions remains remarkably stable when I account for other important determinants of caste-based discrimination. The second column of Table 3 shows that the relationship between SC quotas and street exclusions is independent from the share of SC households. This result is important because the share of one's peers living in one's village is likely to affect one's living conditions from a network perspective, and caste is a strong network basis (Munshi, 2011). Moreover, the composition of a population can affect the incidence of conflicts between subgroups of the population (through different theoretical channels, as discussed in Esteban \& Ray, 2011). Since some state administrations use the share of SCs in each GP to allocate quotas, any relationship between the share of SC in the village and the living conditions of the SC could bias the result of column 1. However, if we compare the results of columns 1 and 2 of Table 3, the coefficient of interest is perfectly stable.

Column 3 of Table 3 documents that SC Pradhans elected through different election formats - with an SC quota or not - have heterogenous effects on caste-based discrimination. Indeed, $S C \times S C \_p r a d h$ is a dummy equal to one for SC households who live in villages with an SC pradhan, a pradhan who may have been elected during an SC quota or outside of it. SC Pradhans elected outside SC quotas appear 
Table 3: Effect of SC quotas on SC households declarations of street exclusion
(1)
(2)
(3)
(4)
(5)

Dependent variable: caste-based exclusion from streets

$\begin{array}{lccccc}\text { SC } \times \text { Quota_SC } & -0.10^{* * * *} & -0.10^{* * *} & -0.14 * * * & -0.14 * * * & -0.14 * * * \\ & (0.02) & (0.02) & (0.03) & (0.01) & (0.03) \\ \text { SC } \times \text { Share_SC } & & -0.06^{* *} & -0.07 * * * & -0.07 * * * & -0.07 * * * \\ & & (0.02) & (0.02) & (0.01) & (0.02) \\ \text { SC } \times \text { Pradh_SC } & & 0.05 * * & 0.05 * * * & 0.05 * * \\ & & (0.02) & (0.01) & (0.02) \\ \text { SC } \times \text { Intermediary_Quota_SC } & & & 0.02 & 0.02 \\ & & & & (0.01) & (0.06) \\ \text { SC } \times \text { Intermediary_Pradh_SC } & & & & & -0.00 \\ & & & & & (0.06) \\ & & & & & \\ \text { Observations } & 79,972 & 79,972 & 79,972 & 79,972 & 79,308 \\ \text { R-squared } & 0.19 & 0.19 & 0.19 & 0.19 & 0.19\end{array}$

Robust standard errors in parentheses are clustered two ways by year*village*caste and household levels. All specifications include year*village, year*caste, and household fixed effects. *** $\mathrm{p}<0.01, * * \mathrm{p}<0.05$, * $\mathrm{p}<0.1$.

to worsen SCs' exclusions while the net effect of SC quotas remains unchanged (the net effect is equal to the coefficient on SC quota, minus the coefficient on SC Pradhan). While the result on SC Pradhan may be surprising, section 5.2 argues that it is the consequence of overlapping identities. Indeed, the SC Pradhan variable actually combines a caste effect and a gender quota effect which may interact in unexpected manners.

The two last columns of Table 3 focus on the persistence in time of the relationship between SC quotas and street exclusions. The incidence of an SC quota between 1996 and 2006 has no effect on caste-based exclusion declarations by SC households. Be it with or without the control for SC pradhans elected outside SC quotas, the effect of intermediary quotas on current exclusions is a precisely estimated zero (columns 4 and 5 of Table 3). Thus, while ongoing quotas reduce exclusions, the effect does not last.

Thus, Table 3 documents that ongoing SC quotas sharply decrease the number of street exclusions declared by SC households, and that the effect is restricted to ongoing quotas. These two results are the main results of this article. From a policy-maker's perspective, a transitory effect of quotas on street exclusions may be worrisome: it means that quotas may not be a suitable tool for changing behaviors in 
the long run. However, the results are actually mixed. Indeed, ongoing quotas have an important impact. Moreover, in Beaman et al. (2009), a repetition of quotas is crucial for changing the perception of female leaders, so that it could be the case that a repetition of caste quotas is crucial for the enduring effect of quotas.

\subsection{Cross Section Results and Exploitation of a Recall Question}

A major limitation of the above analysis is that it relies on a recall question. The 1996 exclusion figure comes from a recall question asked in the 2006 survey. This paper is not the first to use a recall question on perceptions (for example, Vicente, 2010, uses a recall question to measure corruption). Nonetheless, it is important to investigate the consequences of this choice since recall biases may induce measurement errors. I thus first check the robustness of the results in a cross-section setting, and second the (non)existence of a link between quotas in 2006 and street exclusion in 1996.

A first essential observation is that the results are robust to the use of a cross-section specification. I use the following cross-section specification:

$$
\text { Street_exclu } u_{i v}=\beta_{1}+\beta_{2} S C_{i} \times Q u o t a \_S C_{v}+\beta_{3}^{\prime} X_{i}+F E_{v}+\eta_{i v}
$$

The coefficient of interest is $\beta_{2}$. It tells whether the declaration of exclusion of an SC household $i$ in village $v$ in 2006 is affected by the fact that the current Pradhan of the village is elected on an SC quota. $X_{i}$ is a vector of household-level controls which can be related to the household's social status in the village. $X_{i}$ contains the household head's caste category, sex, education level (above or below primary), age, income, and a binary variable telling whether the household's main source of income is agriculture. $F E_{v}$ are village fixed effects, to account for all village-level unobservables. The error term, $\eta_{i v}$ is clustered at the level of the variable of interest, namely caste categories within villages.

The cross section results in Table 4 are consistent with the panel results in Table 3, and play against the concern that the recall question induces measurement error. In 2006, SC households living in a village with an SC quota are about 10\% less likely to suffer from caste-based street exclusions (columns 1 to 6 of Table 4). ${ }^{15}$ Once again, the result is independent of the share of SC households in the village (comparison of columns 1 and 2). Moreover, controlling for declarations of caste-based exclusions in 1996 (the recall question) has no effect on the magnitude of the coefficient of interest, although it improves the precision of the estimation (comparison of columns 2 and 3, Table 4). Both observations ensure that answers to the recall question are unbiased and provide relevant information. Indeed, a change in the magnitude of the coefficient would have been consistent with a recall bias among households experiencing a quota in 2006 
Table 4: Effect of SC quotas on SC street exclusions in 2006
(1)
(2)
(3)
(4)
(5)
(6)

Dependent variable: caste-based exclusion from streets in 2006

\begin{tabular}{|c|c|c|c|c|c|c|}
\hline \multirow[t]{2}{*}{$\mathrm{SC} \times$ Quota_SC } & $-0.09 * *$ & $-0.09 * *$ & $-0.09 * * *$ & $-0.13 * * *$ & $-0.13 * * *$ & $-0.13 * * *$ \\
\hline & $(0.05)$ & $(0.05)$ & $(0.03)$ & $(0.04)$ & $(0.04)$ & $(0.04)$ \\
\hline \multirow[t]{2}{*}{$\mathrm{SC}$} & $0.47 * * *$ & $0.45^{* * *}$ & $0.11 * * *$ & $0.11 * * *$ & $0.11 * * *$ & $0.11 * * *$ \\
\hline & $(0.03)$ & $(0.05)$ & $(0.03)$ & $(0.03)$ & $(0.03)$ & $(0.03)$ \\
\hline \multirow[t]{2}{*}{ SC $\times$ Share_SC } & & 0.10 & 0.00 & -0.04 & -0.05 & -0.04 \\
\hline & & $(0.16)$ & $(0.09)$ & $(0.09)$ & $(0.10)$ & $(0.10)$ \\
\hline \multirow[t]{2}{*}{ 1996_street_exclusion } & & & $0.57 * * *$ & $0.57 * * *$ & $0.57 * * *$ & $0.57 * * *$ \\
\hline & & & $(0.03)$ & $(0.03)$ & $(0.03)$ & $(0.03)$ \\
\hline \multirow[t]{2}{*}{ SC $\times$ Pradhan_SC } & & & & 0.05 & 0.05 & 0.04 \\
\hline & & & & $(0.03)$ & $(0.03)$ & $(0.03)$ \\
\hline \multirow[t]{2}{*}{ SC $\times$ Previous_Quota_SC } & & & & & 0.02 & $0.14 * * *$ \\
\hline & & & & & $(0.04)$ & $(0.04)$ \\
\hline \multirow[t]{2}{*}{ SC $\times$ Previous_Pradhan_SC } & & & & & & $-0.13 * * *$ \\
\hline & & & & & & $(0.02)$ \\
\hline Observations & 40,045 & 40,045 & 40,045 & 40,045 & 40,045 & 39,713 \\
\hline R-squared & 0.33 & 0.33 & 0.58 & 0.58 & 0.58 & 0.58 \\
\hline
\end{tabular}

since the state administration allocates quotas independently of inter-caste relationships in each village. As for the precision of the estimate, if recall declarations were random, controlling for these declarations would not affect it. Finally, the non persistence of the effect in columns 5 and 6 is also consistent with the panel estimates: intermediary SC quotas do not affect current street exclusions (columns 5 and 6 of Table 4).

A second observation supporting the credibility of the recall variable is that the answers of SC households for 1996 exclusions are independent of the treatment at the moment of the survey (electoral quotas). I transform Equation 2 to check the relationship between street exclusions in 1996 (used as an explained variable) and quotas in 2006 (used as an explanatory variable). My concern would be that ongoing quotas could induce a recall bias by making SC households over-optimistic or pessimistic about the past. However, Appendix Table A2 shows that an SC quota in 2006 does not have any impact on SC households' answers to the 1996 street exclusion question. 
Taken together, these results reduce the concern that answers to the recall question could bias the main results. The recall variable provides relevant information and it is not biased by ongoing SC quotas.

\subsection{Robustness}

I check the main results against two additional concerns: the interpretation of the quota variable, and the consequences of different sample definitions.

Focusing on the measure of quotas, the main results are robust to the usual setting of a difference-indifference. The coefficient of interest stays unchanged when I delete from the sample all villages with an SC quota before 2006 (column 1 in Appendix Table A3). The main results are also robust to two placebo tests. I first check that the religion-based exclusions of Muslim households do not react to SC quotas. I should not observe any reaction since religion and caste are different grounds for exclusion, and the survey records these exclusions in different variables. The percentage of Muslim households excluded from streets because of their religion drops from 27\% to 16\% between 1996 and 2006. But the decline in Muslim households' exclusions is independent from SC quotas (column 2, Appendix Table A3). Conversely, gender quotas, meant to empower women, do not have an effect on the caste-based exclusions of SC households (the aggregate effect of gender quota and female Pradhan is insignificant in column 3, Appendix Table A3).

Results are also robust to two alternative sample definitions. In columns 1 and 2 of Appendix Table A4, I include only SC households, since they declare most of the street exclusions. In column 3 and 4, I include all Indian states even if there is less variation in street exclusions outside of the Hindi Belt. Both the significance and the magnitude of the coefficient of interest stay constant across alternative samples. Moreover, the effect remains limited to ongoing quotas, intermediary quotas have no effect on current street exclusion in either specification of Appendix Table A4 (for the intermediary electoral term in column 4 , even if each variable is significant, the aggregate effect of SC quota and SC Pradhan is insignificant).

\section{Discussion}

\subsection{Interpretation of the main Results}

Following the literature (detailed in section 2.4), the decrease of caste-based exclusions during SC quotas could circulate through different channels. Summing up, these potential channels are: improved access to public goods enforced or negotiated by the minority leader, a change in the organization, solidarity, aspirations or feeling of legitimacy of the minority members, and a change in either the stereotypes or the 
perception of the social norm of the majority members. In this section, I discuss the relevance of these channels with respect to their implications in the medium run (after the end of the term with an electoral quota), and in view of some auxiliary results.

Given the transitory effect of quotas on exclusions, the two most relevant channels appear to be either a change in the perceived social norm, or a pivotal part played by an SC Pradhan. Indeed, several of the reasons why SC quotas may affect the social norm are temporary changes. Chauchard (2014) lists four essential changes induced by ongoing SC quotas: a member of the SCs is suddenly in a position of power, ${ }^{16}$ the SC Pradhan has a greater material wealth than is usual for members of the SCs, the quotas increase the contact between SC and non-SC households, ${ }^{17}$ the quotas may create new channels of communication between the SC households of the village and the formal and informal institutions at a higher political level. The first and third changes of this list mechanically disappear at the end of the quota and the persistence of the fourth is highly uncertain. Similarly, if increased access is due to the Pradhan's direct actions (imposing or negotiating better conditions for SC households), it is obvious that the Pradhan can no longer perform these actions after having left the office.

Alternative channels are harder to reconcile with the main results, given the absence of a link between intermediary quotas and current street exclusions. These channels are essential from an empowerment perspective and may still relevant in the longer run, but I do not document their effect in this article.

Indeed, should increased access be due to a collective action, because the SC quota triggers a change of organization or solidarity among SCs, the collective action should last beyond the end of the quota. Either a genuinely collective action stemming from the people has taken place, therefore making it likely that the organization would survive after the end of the electoral term with an Sc quota, or the mobilization relies on the patronage of the SC Pradhan, not as a fully collective action but as a result of the Pradhan's direct action, and it vanishes when the SC quota ends.

Similarly, if quotas trigger a change in SC households' aspirations and feelings of legitimacy, these changes should not disappear the moment the leader ceases to occupy the Pradhan's seat. ${ }^{18}$ Indeed, different studies find long-lasting effects of interventions that affect the aspirations or feeling of legitimacy of minority members. On electoral quotas, Iyer et al. (2012) show a clear change of trend in the manner that women voice their concerns after gender quotas; their effect is not restricted to places with an ongoing gender quota. In other contexts, being assigned to a gender-biased teacher in primary school affects the performance of Israeli students in both middle and high school, and which subjects students choose several years later, in high school (Lavy \& Sand, 2015). Moreover, it is possible to reduce the gap in test scores between black and white students in the US by simply making students write short essays that "reaffirm their sense of personal adequacy" (Cohen, Garcia, Apfel, \& Master, 2006). Writing such an 
Table 5: The effect of quotas through time, and on labor market discrimination

\begin{tabular}{|c|c|c|c|c|c|}
\hline & $\begin{array}{c}\text { (1) } \\
\text { street_exclu }\end{array}$ & $\begin{array}{c}\text { (2) } \\
\text { discr_job head }\end{array}$ & $\begin{array}{c}\text { (3) } \\
\text { discr_job head }\end{array}$ & $\begin{array}{c}\text { (4) } \\
\text { discr_job }\end{array}$ & $\begin{array}{c}\text { (5) } \\
\text { discr_job }\end{array}$ \\
\hline SC $\times$ Quota_2nd_year & $\begin{array}{l}-0.051 \\
(0.04)\end{array}$ & & & & \\
\hline $\mathrm{SC} \times$ Quota_3rd_year & $\begin{array}{c}-0.28 * * * \\
(0.06)\end{array}$ & & & & \\
\hline $\mathrm{SC} \times$ Quota_4th_year & $\begin{array}{c}-0.13 * * * \\
(0.03)\end{array}$ & & & & \\
\hline SC $\times$ Quota_5th_year & $\begin{array}{c}-0.15^{* * *} \\
(0.04)\end{array}$ & & & & \\
\hline $\mathrm{SC} \times$ Quota_SC & & $\begin{array}{c}0.05^{* * * *} \\
(0.02)\end{array}$ & $\begin{array}{l}0.05^{* *} \\
(0.02)\end{array}$ & $\begin{array}{c}0.00 \\
(0.02)\end{array}$ & $\begin{array}{c}0.01 \\
(0.02)\end{array}$ \\
\hline $\mathrm{SC} \times$ Pradhan_SC & $\begin{array}{l}0.05^{* *} \\
(0.02)\end{array}$ & $\begin{array}{c}-0.04 * * \\
(0.02)\end{array}$ & $\begin{array}{c}-0.04 * * \\
(0.02)\end{array}$ & $\begin{array}{l}-0.01 \\
(0.02)\end{array}$ & $\begin{array}{l}-0.01 \\
(0.02)\end{array}$ \\
\hline SC $\times$ Intermediary_Quota_SC & & & $\begin{array}{l}-0.00 \\
(0.02)\end{array}$ & & $\begin{array}{l}0.03 \\
(0.02)\end{array}$ \\
\hline $\mathrm{SC} \times$ Intermediary_Pradhan_SC & & & $\begin{array}{l}-0.00 \\
(0.02)\end{array}$ & & $\begin{array}{l}-0.01 \\
(0.02)\end{array}$ \\
\hline $\mathrm{SC} \times$ Share_SC & $\begin{array}{c}-0.07 * * * \\
(0.02)\end{array}$ & $\begin{array}{l}-0.03^{*} \\
(0.02)\end{array}$ & $\begin{array}{l}-0.03 \\
(0.02)\end{array}$ & $\begin{array}{l}-0.00 \\
(0.01)\end{array}$ & $\begin{array}{l}-0.00 \\
(0.01)\end{array}$ \\
\hline Observations & 79,972 & 79,972 & 79,308 & 79,970 & 79,306 \\
\hline R-squared & 0.19 & 0.01 & 0.01 & 0.03 & 0.03 \\
\hline
\end{tabular}

Robust standard errors in parentheses are clustered two ways by year*village*caste and household levels. All specifications include year*village and year*caste and household fixed effects. $S C * q u o t a \_2 n d \_y e a r$ is equal to one for SC households living in one of the 4 villages where an SC Pradhan has been elected, on an SC quota, for more than one year but less than two years. I follow the same logic to create $S C * q u o t a \_3 r d \_y e a r$ (2 villages), $S C * q u o t a \_4 t h \_y e a r$ (7 villages), and $S C * q u o t a \_5 t h \_y e a r(11$ villages). discr_job head is equal to one if the respondent declares that he or she suffers from caste-based discrimination on the labor market, discr_job is equal to one if the respondent declares that other members of his or her household suffer from caste-based discrimination on the labor market. $* * * \mathrm{p}<0.01, * * \mathrm{p}<0.05$, $* \mathrm{p}<0.1$.

essay at the beginning of one term still significantly affects students' performances more than two years after the intervention (Cohen, Garcia, Purdie-Vaughns, Apfel, \& Brzustoski, 2009).

The stereotype channel is also inconsistent with a transitory impact of quotas. If non-SC households' stereotypes were changed by their contact with a low caste leader, they should not change back to seg- 
regation at the departure of the leader. The point of Allport's contact theory is that there is inertia in stereotypes (Allport, 1954), and field experiments testing the contact hypothesis on school children of different races document long lasting effects (Slavin, 1979).

Two auxiliary results go in the direction of the above discussion: they are consistent with the Pradhan and social norm channels, and inconsistent with several of the alternative channels. First, quotas have a significant effect on street exclusions only after the end of the second year of the electoral term (for villages with an SC quota during that electoral term, column 1, Table 5). This delayed effect is not consistent with the immediate update in aspirations observed in field experiments (Hoff \& Pandey, 2006).

Second, SC quotas do not improve SCs' perception of caste-based discrimination on the job market (columns 2 to 5, Table 5). Discrimination on the job market - as perceived by respondents - declined by one to three percent between 1996 and 2006 (one percent decline in discrimination against themselves, three percent in discrimination against their relatives). However, SC quotas have no effect, or a worsening effect, on these variables (in columns 2 and 3 of Table 5; the aggregate effect of SC quotas and SC Pradhans is significant and negative although the magnitude is small). These results are inconsistent with a change in the non-SC households' stereotypes because, if stereotypes evolve, they should do so in both the public sphere (street exclusions) and the private sphere (work-related interactions). For the same reason, these results are hard to reconcile with an interpretation of the variable of exclusion from streets as a measure of respondents' perceptions of their legitimacy, independently of the actions of members of the dominant castes.

Altogether, these elements point toward a change in the - public - behavior of members of the dominant castes during SC quotas. The first incidence of an SC quota in a village thus changes - and by a good deal - an important dimension of discrimination, even if the effect does not last.

\subsection{SC Pradhans and Gender Quotas}

In this subsection, I discuss why in Table 3, SC Pradhans elected outside SC quotas are shown to worsen the situation of SC households. At first sight, it seems puzzling - if not worrying - that the elections of SC Pradhans inside and outside SC quotas have contradictory effects. However, we need to take overlapping identities in account and these apparently contradictory effects may be due to unexpected interactions between the leader's caste and the incidence of gender quotas.

The 19 elections of SC Pradhans outside SC quotas are endogenous. In particular, all these elections but one have happened either during a gender quota (15 elections), or after an SC quota during the previous electoral term ( 3 elections). As a result, more than three quarters of the SC Pradhans elected outside SC quotas are elected on gender quotas. Incidentally, SC households are more numerous in 
Table 6: Caste shares for Pradhans and constituents in 1996 and 2006 elections without any caste quota Villages without any quota Villages with only a gender quota

\begin{tabular}{lccccc} 
& \multicolumn{2}{c}{$(58$ elections $)$} & & \multicolumn{2}{c}{$(67$ elections $)$} \\
\cline { 2 - 3 } \cline { 5 - 6 } Caste (in \%) & Pradhan & Population & & Pradhan & Population \\
\hline SC & 10 & 20 & & 22 & 21 \\
ST & 0 & 6 & & 5 & 5 \\
OBC & 42 & 53 & & 46 & 52 \\
OC & 48 & 21 & & 27 & 22 \\
Total & 100 & 100 & & 100 & 100 \\
\hline
\end{tabular}

villages where SC Pradhans were elected, but they remain a minority of the overall population (the share of SC households in villages with SC Pradhans elected outside quotas is $29 \%$, against $18 \%$ in villages without an SC Pradhan).

Gender and caste may interact in at least three ways, even if gender quotas by themselves do not affect caste-based exclusions (column 5 of Appendix Table A3). First, the election of an SC woman may lead to a backlash against members of the SCs. Brown and Chowdhury (2017) show that, in theory, affirmative action may increase sabotage activity by members of the dominant group. In our case, a gender quota disqualifies the traditional - high-caste male - elite from running for office. The re-allocation of seats across castes clearly takes place at the benefit of the SCs, and at the expense of the dominant castes (first and fourth rows of Table 6, one can see it either as good news for members of the SCs, or bad news for members of other castes, respectively Buch, 2013; Cassan \& Vandewalle, 2017). By construction, such competition cannot occur during a caste quota.

SC female Pradhans may also face specific difficulties in implementing their preferred policies. Bardhan et al. (2010) document that SC female Pradhans target SC beneficiaries more than non-SC female Pradhans do, but still target them less than male Pradhans do (whether SC or non-SC). For Bardhan et al. (2010), this result is a consequence of the lack of socialization of newly elected female Pradhans, which prevents SC women from implementing traditional patronage.

Finally, caste-based and gender-based preferences may not converge. In a situation symmetric with ours, Clots-Figueras (2011) shows that the effect of gender on vote patterns is different between low caste women (elected during SC ST quotas in state elections) and higher-caste women (elected outside quotas). She argues that this difference may come from the fact that gender and class identities can lead to contradictory preferences. Moreover, gender quotas may exacerbate differences in preferences if they strengthen the gender identity of the leader. Indeed, in laboratory experiments, insisting on the ethnicity 
versus gender of Asian women affects their math and verbal performances in opposite directions, each time consistently with the racial and gender stereotypes (Shih, Pittinsky, \& Trahan, 2006).

The fact that almost all SC Pradhans - outside SC quotas - are elected on a gender quota makes these elections extremely specific. As a result, the coefficient for SC Pradhans mixes many effects, and in particular the effects of gender and caste. The above discussion outlines three reasons why the interaction of gender and caste effects is important to keep in mind, and why it may be consistent with a worsening of caste-based discrimination. More broadly, this discussion calls for further research on the notion of the intersection of different identities and the way that it shapes actions.

\section{Conclusion}

This paper investigates the effect of electoral quotas on caste-based exclusions from streets. Street exclusion is of the forms that caste-based discrimination takes in India. $44.5 \%$ households members of the SC still suffered from a caste-based exclusion in 2006 despite the fact that caste-based discrimination has been anti-constitutional since 1949 .

I provide robust evidence that electoral SC quotas in GPs sharply decrease caste-based discrimination. Ongoing SC quotas decrease the likelihood of street exclusion by about one fifth for SC households. However, the impact is restricted to ongoing quotas. Building upon the literature, these results are consistent with a change in the behavior of members of the dominant castes. These results are inconsistent with either a change in stereotypes of members of the dominant castes, or a change in the aspirations of members of the SCs.

The main contribution of the paper is to document that electoral quotas do affect everyday discrimination. I show that the first incidence of a SC quota in a village is enough to temporarily reduce caste-based discrimination. This result is in line with Chauchard (2014) who shows that caste quotas decrease the declarations of intent to discriminate. Thus, local electoral quotas in India seem to fulfill the desired effects of a quota in at least three dimensions. First, quotas sometimes lead to redistribution (Besley et al., 2004; Chattopadhyay \& Duflo, 2004, this is true of both caste and gender quotas, respectively). ${ }^{19}$ Second, and more importantly, leaders elected thanks to quotas perform equally or better than their counterfactuals in terms of public goods provision or observable characteristics (for both gender and caste quotas, respectively Duflo, 2005; Munshi \& Rosenzweig, 2015). Last but not least, quotas help reduce discrimination, be it the everyday caste-based discrimination described in this article or gender discrimination (Beaman et al., 2009).

The temporary nature of the effect of quotas can be worrisome if the objective of the policy-maker 
is to repeal quotas after they have induced a change in practices. However, a reduction of caste-based discrimination during quotas implemented for the first time is already an encouraging result. Repeating exposure to the quota may induce a more persistent result. For example, in Beaman et al. (2009), a repetition of the gender quota is necessary for gender quotas to affect significantly gender bias in local Indian elections. These findings call for further work on the various dimensions of caste-based and gender-based discrimination after a repetition of quotas.

Overall, recent empirical evidence, including the results presented here, suggests that affirmative action policies allow for a big push towards an immediate redistribution and may be helpful in changing mentalities in the short run. This evidence goes beyond the situation in India since the effects of affirmative action have also been reported for the US and South Africa (respectively H. Holzer \& Neumark, 2000; Seekings, 2008). However, while affirmative action remains an effective policy tool for immediate effects, much more work is needed to understand the potential complementarities arising from combining affirmative action with other policies. For instance, Paluck and Green (2009) review other de-biasing techniques such as workplace diversity training or media campaigns. Exploring potential complementarities between these polices is in my opinion a promising avenue in the long term quest for a stable non-discriminatory equilibrium.

\section{References}

Allport, G. (1954). The nature of prejudice. Addison-Wesley Pub. Co. Doi: 978-0201001792

Altonji, J. G., Elder, T. E., \& Taber, C. R. (2005). Selection on observed and unobserved variables: Assessing the effectiveness of catholic schools. Journal of Political Economy, 113(1), 151-184. Doi: http://dx.doi.org/10.1086/426036

Anderson, S. (2011, September). Caste as an impediment to trade. American Economic Journal: Applied Economics, 3(1), 239-63. Doi: 10.1257/app.3.1.239

Angrist, J. D. (2001). Estimation of limited dependent variable models with dummy endogenous regressors. Journal of Business \& Economic Statistics, 19(1), 2-28. Doi: 10.1198/07350010152472571

Anukriti, S., \& Chakravarty, A. (2015, April). Political Aspirations in India: Evidence from Fertility Limits on Local Leaders (IZA Discussion Papers No. 9023).

Arrow, K. (1973). The theory of discrimination. In Discrimination in labor markets (Princeton University Press ed., pp. 3-33).

Banerjee, A., Duflo, E., Ghatak, M., \& Lafortune, J. (2013). Marry for what? Caste and mate selection in modern India. American Economic Journal: Microeconomics, 5(2), 33-72. Doi: 
10.1257/mic.5.2.33

Banerjee, A., \& Somanathan, R. (2007). The political economy of public goods: Some evidence from india. Journal of Development Economics, 82(2), 287-314. Doi: http://www.elsevier.com/wps/find/journaldescription.cws_home/505546/description\#description

Bardhan, P., Mookherjee, D., \& Parra-Torrado, M. (2010). Impact of political reservations in West Bengal local governments on anti-poverty targeting. Journal of Globalization and Development, 1(1), 1-38. Doi: https://doi.org/10.2202/1948-1837.1025

Beaman, L., Chattopadhyay, R., Duflo, E., Pande, R., \& Topalova, P. (2009, November). Powerful women: Does exposure reduce bias? Quarterly Journal of Economics, 124(4), 1497-1540. Doi: http://www.mitpressjournals.org/loi/qjec

Beaman, L., Duflo, E., Pande, R., \& Topalova, P. (2012). Female leadership raises aspirations and educational attainment for girls: A policy experiment in India. Science, 335(6068), 582-586. Doi: $10.1126 /$ science. 1212382

Becker, G. S. (1957). The economics of discrimination. Chicago: University of Chicago Press. Doi: 9780226041049

Bertrand, M., \& Duflo, E. (2016, February). Field experiments on discrimination (Working Paper No. 22014). National Bureau of Economic Research. Doi: 10.3386/w22014

Bertrand, M., Hanna, R., \& Mullainathan, S. (2010, February). Affirmative action in education: Evidence from engineering college admissions in India. Journal of Public Economics, 94(1-2), 16-29. Doi: $10.3386 /$ w13926

Besley, T., Pande, R., Rahman, L., \& Rao, V. (2004). The politics of public good provision: Evidence from Indian local governments. Journal of the European Economic Association, 2(2-3), 416-426. Doi: http://www.mitpressjournals.org/loi/jeea

Bhalotra, S., Clots-Figueras, I., \& Iyer, L. (2013, November). Path-breakers: How does women's political participation respond to electoral success (Economics Discussion Papers No. 740). University of Essex, Department of Economics. Doi: 10.2139/ssrn.2350805

Borooah, V. K. (2012). Social identity and educational attainment: The role of caste and religion in explaining differences between children in india. The Journal of Development Studies, 48(7), 887-903. Doi: 10.1080/00220388.2011.621945

Borooah, V. K. (in press). Caste and regional influences on the practice of 'untouchability' in india. Development and Change, n/a-n/a. Doi: 10.1111/dech.12311

Borooah, V. K., Diwakar, D., Mishra, V. K., Naik, A. K., \& Sabharwal, N. S. (2014). Caste, inequality, and poverty in India: a re-assessment. Development Studies Research, 1(1), 279-294. Doi: 


\section{$10.1080 / 21665095.2014 .967877$}

Bros, C., \& Couttenier, M. (2015). Untouchability, homicides and water access. Journal of Comparative Economics, 43(3), 549 - 558. Doi: http://dx.doi.org/10.1016/j.jce.2014.12.001

Brown, A., \& Chowdhury, S. M. (2017). The hidden perils of affirmative action: Sabotage in handicap contests. Journal of Economic Behavior Organization, 133, 273 - $284 . \quad$ Doi: http://dx.doi.org/10.1016/j.jebo.2016.11.009

Buch, N. (2013). From oppression to assertion: Women and panchayats in india. Taylor \& Francis. Doi: 978-0415596312

Cameron, A. C., Gelbach, J. B., \& Miller, D. L. (2011). Robust inference with multiway clustering. Journal of Business \& Economic Statistics, 29(2), 238-249. Doi: http://dx.doi.org/10.1198/jbes.2010.07136

Cassan, G. (2015, November). Identity-based policies and identity manipulation: Evidence from colonial punjab. American Economic Journal: Economic Policy, 7(4), 103-31. Doi: 10.1257/pol.20130290

Cassan, G., \& Vandewalle, L. (2017). Overlapping identities and identity based policies: Evidence from gender quotas in india. mimeo.

Chattopadhyay, R., \& Duflo, E. (2004). Women as policy makers: Evidence from a randomized policy experiment in India. Econometrica, 72(5), 1409-1443. Doi: 10.1111/j.1468-0262.2004.00539.x

Chauchard, S. (2014, May). Can descriptive representation change beliefs about a stigmatized group? Evidence from rural India. American Political Science Review, 108(02), 403-422. Doi: $10.1017 / \mathrm{S} 0003055414000033$

Clots-Figueras, I. (2011). Women in politics: Evidence from the Indian states. Journal of Public Economics, $95(7$ - 8), 664 - 690. Doi: http://dx.doi.org/10.1016/j.jpubeco.2010.11.017

Cohen, G. L., Garcia, J., Apfel, N., \& Master, A. (2006, September). Reducing the racial achievement gap: A social-psychological intervention. Science, 313, 1307-1310. Doi: $10.1126 /$ science. 1128317

Cohen, G. L., Garcia, J., Purdie-Vaughns, V., Apfel, N., \& Brzustoski, P. (2009). Recursive processes in self-affirmation: Intervening to close the minority achievement gap. Science, 324(5925), 400-403. Doi: $10.1126 /$ science.1170769

Deliège, R. (2004). Les castes en inde aujourd'hui (1st ed.). Paris: Presses universitaires de France.

Deshpande, A. (2000, May). Does Caste Still Define Disparity? A Look at Inequality in Kerala, India. American Economic Review, 90(2), 322-325. Doi: 10.1257/aer.90.2.322

Deshpande, A. (2015). Dominant or backward?: Political economy of demand for quotas by Jats, Patels, 
and Marathas. , 52(19), 781 - 90. Doi: 10.13140/RG.2.2.24573.97766

Duflo, E. (2005, April). Why political reservations? Journal of the European Economic Association, $3(2 / 3), 668-678$.

Dunning, T. (2010). Do quotas promote ethnic solidarity? Field and natural experimental evidence from India. working paper, Yale University.

Dunning, T., \& Nilekani, J. (2013). Ethnic quotas and political mobilization: Caste, parties, and distribution in indian village councils. American Political Science Review, 107(1), 35â56. Doi: $10.1017 / \mathrm{S} 0003055412000573$

Esteban, J., \& Ray, D. (2011, September). Linking conflict to inequality and polarization. American Economic Review, 101(4), 1345-1374.

Fisher v. University of Texas at Austin. (2016, june). 579 U.S. n.a.

Galanter, M. (1984). Competing equalities: law and the backward classes in india. Oxford.

Ghani, E., Kerr, W. R., \& O'Connell, S. D. (2014). Political reservations and women's entrepreneurship in India. Journal of Development Economics, 108, 138 - $153 . \quad$ Doi: http://dx.doi.org/10.1016/j.jdeveco.2014.01.008

Gille, V. (2014). How to get a job in the public sector? The role of local politics and caste networks in affirmative action programs in India. mimeo.

Hanna, R. N., \& Linden, L. L. (2012). Discrimination in grading. American Economic Journal: Economic Policy, 4(4), 146-68. Doi: 10.1257/pol.4.4.146

Hidden apartheid caste discrimination against India's "untouchables". (2007). Human Rights Watch Report.

Hirschman, A. (1970). Exit, voice, and loyalty: Responses to decline in firms, organizations, and states. Harvard University Press. Doi: 9780674276604

Hoff, K., \& Pandey, P. (2006, May). Discrimination, social identity, and durable inequalities. American Economic Review, 96(2), 206-211. Doi: http://www.aeaweb.org/aer/

Hoff, K., \& Pandey, P. (2014). Making up people - the effect of identity on performance in a modernizing society. Journal of Development Economics, 106, 118 - 131. Doi: http://dx.doi.org/10.1016/j.jdeveco.2013.08.009

Holzer, H., \& Neumark, D. (2000, September). Assessing affirmative action. Journal of Economic Literature, 38(3), 483-568. Doi: 10.1257/jel.38.3.483

Holzer, H. J., \& Neumark, D. (2008). Affirmative action. In S. N. Durlauf \& L. E. Blume (Eds.), The new palgrave dictionary of economics. Basingstoke: Palgrave Macmillan.

Iyer, L., Mani, A., Mishra, P., \& Topalova, P. (2012, July). The power of political voice: Women's 
political representation and crime in India. American Economic Journal: Applied Economics, 4(4), 165-93. Doi: 10.1257/app.4.4.165

Jaffrelot, C. (2003). India's silent revolution: The rise of the lower castes in north indian politics. Columbia University Press.

Jensenius, F. R. (2015, July). Development from representation? A study of quotas for the scheduled castes in India. American Economic Journal: Applied Economics, 7(3), 196-220. Doi: 10.1257/app.20140201

Jensenius, F. R. (in press). Social justice through inclusion: The consequences of electoral quotas in india. Oxford University Press.

Krook, M. L. (2009). Quotas for women in politics. Oxford University Press. Doi: 978-0199740277

Kumar, S. M. (2013). Does access to formal agricultural credit depend on caste? World Development, 43, 315 - 328. Doi: http://dx.doi.org/10.1016/j.worlddev.2012.11.001

LaPiere, R. T. (1934). Attitudes vs. actions. Social Forces, 13, 230-237.

Lavy, V., \& Sand, E. (2015, January). On the origins of gender human capital gaps: Short and long term consequences of teachers' stereotypical biases (Working Paper No. 2009). National Bureau of Economic Research. Doi: 10.3386/w20909

Macwan, M., Davenport, C., Armstrong, D., Stam, A., Varma, M. K., \& Klassing, A. (2010). Understanding untouchability. Ahmedabad: Navsarjan Trust.

Ministry of Panchayati Raj, Government of India. (n.d.). http://www.panchayat.gov.in.

Munshi, K. (2011, March). Strength in numbers: Networks as a solution to occupational traps. The Review of Economic Studies, 78(3), 1069-1101. Doi: 10.1093/restud/rdq029

Munshi, K., \& Rosenzweig, M. (2015, November). Insiders and Outsiders: Local Ethnic Politics and Public Goods Provision (NBER Working Papers No. 21720). Doi: 10.3386/w21720

Oster, E. (2013, August). PSACALC: Stata module to calculate treatment effects or bounds under proportional selection of observables and unobservables. Statistical Software Components, Boston College Department of Economics.

Oster, E. (2014, November). Unobservable selection and coefficient stability: Theory and evidence. mimeo.

Paluck, E. L., \& Green, D. P. (2009). Prejudice reduction: What works? a review and assessment of research and practice. Annual Review of Psychology, 60(1), 339-367. Doi: 10.1146/annurev.psych.60.110707.163607

Pande, R. (2003). Can mandated political representation increase policy influence for disadvantaged 
minorities? Theory and evidence from india. American Economic Review, 93(4), 1132-1151. Doi: $10.1257 / 000282803769206232$

Phelps, E. (1972). The statistical theory of racism and sexism. American Economic Review, 62(4), 659-61.

Reynolds, A. (2005). Reserved seats in national legislatures: A research note. Legislative Studies Quarterly, 30(2), 301-310. Doi: 10.3162/036298005X201563

Roemer, J. E., \& Trannoy, A. (2015). Equality of opportunity. In A. B. Atkinson \& F. Bourguignon (Eds.), Handbook of income distribution (Vol. 2, p. 217 - 300). Elsevier. Doi: http://dx.doi.org/10.1016/B978-0-444-59428-0.00005-9

Schaffer, M. E. (2005, November). XTIVREG2: Stata module to perform extended IV/2SLS, GMM and AC/HAC, LIML and k-class regression for panel data models. Statistical Software Components, Boston College Department of Economics.

Seekings, J. (2008). The continuing salience of race: Discrimination and diversity in south africa. Journal of Contemporary African Studies, 26(1), 1-25. Doi: 10.1080/02589000701782612

Sengupta, A. (2010). Concept, category and claim: insights on caste and ethnicity from the police in india. , 33(4), 717-736. Doi: 10.1080/01419870903388311

Shah, G., Mander, H., Thorat, S., Deshpande, S., \& Baviskar, A. (2006). Untouchability in rural india. New Delhi ; Thousand Oaks, Calif: SAGE Publications Pvt. Ltd.

Sharma, S. (2015). Caste-based crimes and economic status: Evidence from India. Journal of Comparative Economics, 43(1), 204 - 226. Doi: http://dx.doi.org/10.1016/j.jce.2014.10.005

Shih, M., Pittinsky, T. L., \& Trahan, A. (2006). Domain-specific effects of stereotypes on performance. Self and Identity, 5(1), 1-14. Doi: 10.1080/15298860500338534

Slavin, R. E. (1979). Effects of biracial learning teams on cross-racial friendships. Journal of Educational Psychology, 71(3), 381-387. Doi: 10.1037/0022-0663.71.3.381

Thorat, A., Vanneman, R., Desai, S., \& Dubey, A. (2017). Escaping and falling into poverty in india today. World Development, 93, 413 - 426. Doi: https://doi.org/10.1016/j.worlddev.2017.01.004

Thorat, S., \& Newman, K. S. (2010). Blocked by caste: economic discrimination in modern India. New Delhi: Oxford University Press.

Vicente, P. C. (2010). Does oil corrupt? Evidence from a natural experiment in West Africa. Journal of Development Economics, 92(1), 28 - 38. Doi: http://dx.doi.org/10.1016/j.jdeveco.2009.01.005

Zacharias, A., \& Vakulabharanam, V. (2011). Caste stratification and wealth inequality in india. World Development, 39(10), 1820 - 1833. Doi: http://dx.doi.org/10.1016/j.worlddev.2011.04.026 


\section{Notes}

${ }^{1}$ To be precise, discrimination means that people with similar characteristics - apart from their group identity - in similar circumstances are treated differentially (Bertrand \& Duflo, 2016). Affirmative action means that a person or institution in a position of power actively improves an outcome of interest for a minority, going beyond non-discrimination (H. J. Holzer \& Neumark, 2008).

${ }^{2}$ The seminal works by Chattopadhyay and Duflo (2004) for women, and Besley et al. (2004) for castes, document that leaders elected on quotas favor the members of their group in the allocation of public goods and benefits. However, more recent studies do not confirm this finding (Bardhan et al., 2010; Jensenius, 2015).

${ }^{3}$ Indeed, even if all forms of discrimination were statistical and could be argued to be efficient screening devices in the presence of imperfect information (Arrow, 1973), "[d]iscrimination is no less damaging to its victims for being statistical. And it is no less important for social policy to counter" (Phelps, 1972, p. 661). See Roemer and Trannoy (2015) for a recent discussion of the different notions of equality.

${ }^{4}$ (Macwan et al., 2010) aim is to offer a "general and multi-disciplinary view of current untouchability practices across rural areas in Gujarat (bringing together political science, sociology, law, public policy and community organizing)" (p.vi). The survey was produced by a team of Navsarjan, the RFK Global Advocacy Team from the University of Maryland/Kroc Institute at the University of Notre Dame, and Dartmouth College/University of Michigan. The survey, conducted between 2005 and 2008 , covers 1,589 villages of Gujarat.

${ }^{5}$ Other Indian affirmative action policies are: quotas for public servant positions (Gille, 2014), quotas for higher education institutions (Bertrand, Hanna, \& Mullainathan, 2010), and quotas in state and national assembly elections (respectively Jensenius, 2015; Pande, 2003). The first quotas were introduced by the British administration as early as 1919. The State also passed laws such as the Prevention of Atrocities Act of 1989 to grant spetial protection to members of the SCs and provide de-biasing training to public servants (Sengupta, 2010).

${ }^{6}$ GPs are important in shaping households' actions. For example, beyond the examples already mentioned around quotas, Anukriti and Chakravarty (2015) show that households fertility decisions are significantly impacted by the legal fertility limits imposed on elected members of the local councils.

${ }^{7}$ The constitutional reform is not binding on the OBC quotas. The OBC being a very heterogeneous group, the political acceptability of OBC quotas would have been smaller than what it was for SC and ST and gender quotas. The national state thus left each of the federal states and union territories decide whether or not to impose OBC quotas in Panchayat elections.

${ }^{8}$ The actual survey took place in a series of different waves, between 2006 and 2009. For conciseness, I refer to 2006 as the year of the survey, but I keep in mind the staggered implementation in the empirical analysis.

${ }^{9}$ As a result, still today, STs more often than SCs either live in places where they belong to the majority or form a very small minority. In the REDS2006 sample, $60 \%$ of STs live in villages where STs represent less than $10 \%$ or more than $50 \%$ of the population, while only $10 \%$ of SCs live in villages where SCs make up less than $10 \%$ or more than $50 \%$ of the population.

${ }^{10}$ Specific local wealth patterns means that one sub-caste can be dominated in one village and dominant in another and the consequences in terms of status can be significant in particular for members of the OBCs (see respectively Anderson, 2011; Borooah, 2012, on power imbalance and the within group variety of endowments). On setting the frontier to the low caste, "the very existence of the list [of Scheduled Castes, Tribes, and Other Backward Classes] acts to induce movement across the line into favored categories by manipulation of equivocal nomenclature." (Galanter, 1984, p. 285), a pattern confirmed empirically for members of the OBCs (Cassan, 2015), and which led to recent demonstrations by castes who wanted to benefit from affirmative action (Deshpande, 2015). Lastly, measurement error may come from both a random mis-coding of the question 
and a misunderstanding of it by respondents: only 319 out of 21,528 OC households declare a street exclusion, and $71 \%$ of these households are Muslim households who might have mixed the interpretation of the caste-based exclusion question with the religion-based exclusion question.

${ }^{11} \mathrm{~A}$ GP is often constituted of more than one village. The absence of data on caste group repartition across GPs in India does not allow me to test the balance of the actual share of SCs in each GP. However, the share of SCs in each village already provides both essential information on the conditions of living of the SC households, and a rough proxy of the SC population in the GP. Moreover, quotas do not appear to induce sorting. The village survey contains information on the incidence of out-migration episodes as well as in-migration episodes, even if the data is not collected by caste it provides a first overview. The correlation between SC quotas and migration is insignificant (the p-value of the correlation is 0.56 for in-migration episodes and 0.89 for out-migration episodes).

${ }^{12}$ At least one ST is present in 47 of the 90 villages in the study, but only 5 villages have experienced an ST quota during one of the two terms, and in 2 of these villages the STs never declare any street exclusion. 4 other villages have had an ST quota in both terms, but the impact is not time variant in their case; hence it would be captured by household-level fixed effects.

${ }^{13}$ The use of Linear Probability Models has spread since (Angrist, 2001) and his plea that, ultimately, quantities of interest are marginal effects.

${ }^{14}$ An approach popularized by Cameron, Gelbach, and Miller (2011). I follow the implementation proposed by Schaffer (2005) since it is more efficient for handling an important number of fixed effects.

${ }^{15}$ The estimate is not likely to be driven by unobserved heterogeneity. Indeed, the formal test proposed by Oster (2013) extending the test by Altonji, Elder, and Taber (2005) - yields an absolute value for delta of 5. To compute it, I use column 1 of Table 4 as the parsimonious specification, and the most conservative assumption for the maximum R-squared (namely, $\mathrm{R}$-squared maximum equal to 1). This estimated value of delta is above the rule of thumb suggested by Oster (2014) - namely delta equal to 1.

${ }^{16}$ Although this power is relative, since the Pradhan needs to keep harmonious relationship with members of his or her council, and may sometimes be considered to act as a proxy for local strongmen.

${ }^{17}$ If only geographic contact through visits of the SC leader to non-SCs neighborhoods and vice-versa.

${ }^{18}$ Feeling legitimate is a central aspect of empowerment. A growing literature insists on the "relevance of self-fulfilling prophecies as an explanation for persistent differences in performance between different groups of workers or students" (Bertrand \& Duflo, 2016, p. 52). Hoff and Pandey (2006, 2014) document the relevance of this pattern for caste identities.

${ }^{19}$ Even if these findings do not replicate everywhere (Bardhan et al., 2010; Dunning \& Nilekani, 2013), it is already a big achievement of electoral quotas since the design of the quota, with a single electorate composed of several castes or gender, does not provide an incentive to perform group-based redistribution (Jensenius, in press). 


\section{ONLINE APPENDIX, NOT FOR PUBLICATION}

Table A1: Quotas for the SCs in Jalore Panchayat Samiti (Jalore District). Source: Chauchard (2014)

\begin{tabular}{lcccccc}
\hline & & Quotas & & & & Not Yet Quotas \\
& $\% \mathrm{SC}^{*}$ (Ranked from & in 1995 (First & Quotas & Quotas & Quotas & (Likely quota in \\
GP Name & largest to smallest) & GP elections) & in 2000 & in 2005 & in 2010 & 2015) \\
\hline
\end{tabular}

\begin{tabular}{|c|c|c|c|c|c|c|}
\hline 1. Bakra Road & 30 & 1 & & & & \\
\hline 2. Chura & 28.3 & 1 & & & & \\
\hline 3. Revat & 25.5 & 1 & & & & \\
\hline 4. Sivana & 25.1 & 1 & & & & \\
\hline 5. Bhagli Sindhlan & 25 & 1 & & & & \\
\hline 6. Madgaon & 24.8 & & 1 & & & \\
\hline 7. Meda Uperla & 24 & & 1 & & & \\
\hline 8. Chandan & 23.9 & & 1 & & & \\
\hline 9. Unan & 23.8 & & 1 & & & \\
\hline 10. Bibalsar & 23.7 & & 1 & & & \\
\hline 11. Badanvadi & 23.4 & & & 1 & & \\
\hline 12. Siyana & 21.7 & & & 1 & & \\
\hline 13. Dudsi & 20.3 & & & 1 & & \\
\hline 14. Narnavas & 20.1 & & & 1 & & \\
\hline 15. Bagra & 18.8 & & & & 1 & \\
\hline 16. Debavas & 18.1 & & & 1 & & \\
\hline 17.Dechu & 17.5 & & & & 1 & \\
\hline 18. Godan & 17.3 & & & & 1 & \\
\hline 19. Sankrna & 17.2 & & & & 1 & \\
\hline 20. Noon & 16.8 & & & & 1 & \\
\hline 21. Santhu & 16.7 & & & & 1 & \\
\hline 22. Digaon & 15.5 & & & & & 1 \\
\hline 23. Samtipura & 15.2 & & & & & 1 \\
\hline 24. Samuja & 15 & & & & & 1 \\
\hline 25. Akoli & 14.9 & & & & & 1 \\
\hline 26. Leta & 14.4 & & & & & 1 \\
\hline 27. Odvada & 13.4 & & & & & 1 \\
\hline 28. Deki & 13.3 & & & & & 1 \\
\hline
\end{tabular}

*Based on 2001 Census of India Data

Note: Since members of the SCs constitute less than 20\% of the population in Jalore Panchayat Samiti, 5.5 (that is, either 5 or 6) GPs are supposed to have an SC quota at each electoral period, as is the case here. Assignment of quotas then unfolds in decreasing order, starting with the GPs with the largest SC population share and ending with the GPs with the smallest SC population share. 
Table A2: The (placebo) effect of SC quotas in 2006 on street exclusions of SC households in 1996

(1) (2) (3)

Dependent variable: caste-based exclusion from streets in 1996

$\begin{array}{lccc}\text { SC } \times \text { Quota_SC } & -0.00 & 0.00 & 0.08 \\ & (0.05) & (0.05) & (0.11) \\ \text { SC } & 0.64 * * * & 0.60 * * * & 0.60 * * * \\ & (0.03) & (0.05) & (0.05) \\ \text { SC } \times \text { Share_SC } & & 0.16 & 0.24 \\ & & (0.19) & (0.19)\end{array}$

SC $\times$ Pradhan_SC

$-0.09$

$(0.10)$

$\begin{array}{llll}\text { Observations } & 40,047 \quad 40,047 & 40,047\end{array}$

$\begin{array}{llll}\text { R-squared } & 0.45 & 0.45 & 0.45\end{array}$

Robust standard errors in parentheses are clustered at the year*caste level. All specifications include village fixed effects and control for caste categories, sex, primary education, age, income, and agriculture as the main income source. $* * * \mathrm{p}<0.01$, $* * \mathrm{p}<0.05, * \mathrm{p}<0.1$ 
Table A3: The attribution of quotas and street exclusions

\begin{tabular}{|c|c|c|c|}
\hline & $\begin{array}{c}\text { (1) } \\
\text { Diff-in-diff } \\
\text { no SC quotas } \\
\text { before } 2006\end{array}$ & $\begin{array}{c}\text { (2) } \\
\text { Placebo } \\
\text { religion-based } \\
\text { exclusion }\end{array}$ & $\begin{array}{c}\text { (3) } \\
\text { Placebo } \\
\text { gender-based } \\
\text { quotas }\end{array}$ \\
\hline \multicolumn{4}{|c|}{ Dependent variable: caste-based OR religion-based exclusion from streets } \\
\hline SC $\times$ Quota_SC & $\begin{array}{c}-0.10^{* * *} \\
(0.03)\end{array}$ & & \\
\hline SC $\times$ Pradh_SC & $\begin{array}{c}0.03 \\
(0.02)\end{array}$ & & \\
\hline Mus $\times$ Quota_SC & & $\begin{array}{c}0.05 \\
(0.04)\end{array}$ & \\
\hline Mus $\times$ Pradh_SC & & $\begin{array}{l}-0.01 \\
(0.02)\end{array}$ & \\
\hline SC $\times$ Quota_Women & & & $\begin{array}{c}-0.11^{* * *} \\
(0.03)\end{array}$ \\
\hline SC $\times$ Pradhan_Women & & & $\begin{array}{c}0.14 * * * \\
(0.03)\end{array}$ \\
\hline $\mathrm{SC} \times$ Share_SC & $\begin{array}{c}-0.09 * * * \\
(0.02)\end{array}$ & & $\begin{array}{c}-0.06^{* *} \\
(0.03)\end{array}$ \\
\hline Observations & 70,982 & 79,706 & 79,706 \\
\hline year*village fixed effects & $\mathrm{X}$ & $\mathrm{X}$ & $\mathrm{X}$ \\
\hline year*caste fixed effects & $\mathrm{X}$ & $\mathrm{X}$ & $\mathrm{X}$ \\
\hline year*religion fixed effects & & $\mathrm{X}$ & \\
\hline household fixed effects & $\mathrm{X}$ & $\mathrm{X}$ & $\mathrm{X}$ \\
\hline R-squared & 0.19 & 0.05 & 0.19 \\
\hline
\end{tabular}

Robust standard errors in parentheses are clustered two ways by year*village*caste and household levels. $* * * \mathrm{p}<0.01, * * \mathrm{p}<0.05, * \mathrm{p}<0.1$. 
Table A4: The effect of SC quotas on street exclusions in different samples
(1)
(2)
(3)
(4)

SC households sample

All India sample

Dependent variable: caste-based exclusion from streets

$\begin{array}{lcccc}\text { SC } \times \text { Quota_SC } & -0.12 * * * & -0.11 * * * & -0.13 * * * & -0.15 * * * \\ & (0.03) & (0.03) & (0.02) & (0.02) \\ \text { SC } \times \text { Pradhan_SC } & 0.04 * & 0.04 & 0.06 * * * & 0.06 * * * \\ & (0.03) & (0.03) & (0.02) & (0.02) \\ \text { SC } \times \text { Intermediary_Quota_SC } & & 0.03 & & 0.08 * * \\ & & (0.07) & & (0.03) \\ \text { SC } \times \text { Intermediary_Pradhan_SC } & & -0.03 & & -0.07 * * \\ & & (0.06) & & (0.03) \\ \text { SC } \times \text { Share_SC } & -0.07 * * * & \text { na } & -0.06 * * & -0.07 * * * \\ & (0.02) & \text { na } & (0.03) & (0.03)\end{array}$

Observations

194,846

186,692

year fixed effects

village fixed effects

$\mathrm{X} \quad \mathrm{X}$

year*village fixed effects

$\mathrm{X} \quad \mathrm{X}$

year*caste fixed effects

$\begin{array}{ll}X & X \\ X & \end{array}$

household fixed effects

X $\quad X$

$\mathrm{X}$

$\mathrm{X}$

R-squared

$0.19 \quad 0.19$

$\mathrm{X}$

$\mathrm{X}$

Robust standard errors in parentheses are clustered two ways by year*village*caste and household levels. $* * * \mathrm{p}<0.01, * * \mathrm{p}<0.05, * \mathrm{p}<0.1$. 